\title{
軽量ポリエステルモルタルの調合要因の検討 \\ INFLUENCES OF MIX PROPORTIONING FACTORS ON PROPERTIES OF LIGHTWEIGHT POLYESTER MORTARS
}

\author{
李 侖 洙*, 大濱 嘉彦**, 出村克宣 ${ }^{* * *}$, 井出一直**** \\ Younsu LEE, Yoshihiko OHAMA, Katsunori DEMURA and Kazunao IDE
}

As a model investigation for the development of lightweight polyester concretes with high strength, lightweight polyester mortars using unsaturated polyester resin and lightweight aggregates are prepared with various mix proportions, and tested for slump, working life, apparent specific gravity, flexural and compressive strengths. As a result, their slump and working life can be controlled, and their flexural and compressive strengths are 9.7 to $22.0 \mathrm{MPa}$ and 23.0 to $100.8 \mathrm{MPa}$ respectively at apparent specific gravities of 0.86 to 1.73 . Equations for predicting their compressive strength are proposed for different aggregates.

Keywords : polyester mortars, lightweight aggregates, apparent specific gravity, working life, strength, slump ポリエステルモルタル，軽量骨材，見掛け比重，可使時間，強さ，スランプ

\section{1.はじめに}

建築分野では、セメントコンクリートは耐久的、経済 的な構造材料として常用されているが、他の構造材料に 比べると、強度のわりに質量が大きいことが大きな欠点 である。従って、建築物の巨大化、高層化の進む現代に おいては、軽量、且つ高強度、換言すれば、比強度の大 きなコンクリートを開発する必要性が高まっている。

一方、液状レジンは、その比重がセメントの比重の約 1/3であり、しかも、その接着強さがセメント水和物よ りも相当に高いので、この液状レジンを結合材とし、良 質の軽量骨材を併用するならば、セメントコンクリート よりも比強度の大きいポリマーコンクリートの製造が可 能であると考えられる ${ }^{1}$ 。セメントコンクリートと比較 して、ポリマーコンクリートは、早期に高強度を発現す るばかりでなく、水密性、耐薬品性、耐凍結融解性など に優れる。軽量ポリマーコンクリートにおいても、これ らの利点を利用することができる。

本研究では、液状レジンとして比較的安価な不飽和ポ リエステル樹脂を用いた軽量ポリエステルコンクリート
の開発にとって最も重要な調合設計法の確立を目的とし て、そのモデルとしての軽量ポリエステルモルタルを製 造し、まだ固まらない時のスランプ及び可使時間と硬化 した時の強さ性状に及ぼす調合要因の影響について検討 する。更に、圧縮強さ性状の知見をもとに、軽量ポリエ ステルモルタルの圧縮強さ算定式を提案する。

\section{2. 使用材料}

2. 1 結合材用材料

結合材としては、液状レジンである不飽和ポリエステ ル樹脂 (UP)に、希䣋風としてスチレンモノマー $(\mathrm{St}) 、$ 促 進剤としてオクテン酸コバルトの 8 \% mineral turpentine溶液 $(\mathrm{CoO} \mathrm{c}) 、$ 触媒としてメチルエチルケトン パーオキサイド (MEKP0)を添加したものを使用した。液 状レジンの性質を表 1 に示す。

\section{2 . 2 充填材及び軽量骨材}

充填材としては、重質炭酸カルシウム $\left(\mathrm{CaC}_{3}\right)$ 、中空 ガラス微粉末 $(\mathrm{HG})$ 及び中空フライアッシュ $(\mathrm{HF})$ を、軽量 骨材としては、膨張シェール $(\mathrm{ES}) 、$ 発泡ガラス $(\mathrm{FG}) 、$ 中
* 日本大学工学部建築学科 大学院生. 工修

** 日本大学工学部建築学科 教授 $\cdot$ 工博

*** 日本大学工学部建築学科 助教授 $\cdot$ 工博

**** 日本大学工学部建築学科 大学院生
Graduate Student, Dept. of Architecture, College of Engineering, Nihon Univ., M. Eng.

Prof., Dept. of Architecture, College of Engineering, Nihon Univ., Dr. Eng.

Assoc. Prof., Dept. of Architecture, College of Engineering, Nihon Univ., Dr. Eng.

Graduate Student, Dept. of Architecture, College of Engineering, Nihon Univ. 
表 1 液状レジンの性質

\begin{tabular}{c|c|c|c}
\hline $\begin{array}{c}\text { Specific } \\
\text { Gravity } \\
\left(20^{\circ} \mathrm{C}\right)\end{array}$ & $\begin{array}{c}\text { Viscosity } \\
\left(20^{\circ} \mathrm{C}, \mathrm{mPa} \cdot \mathrm{s}\right)\end{array}$ & $\begin{array}{c}\text { Styrene } \\
\text { Content } \\
(\%)\end{array}$ & Acid Value \\
\hline 1.13 & 325 & 38.0 & 16.9 \\
\hline
\end{tabular}

空溶融アルミナ (HFA) 及び中空ムライト(HM)を使用した。 充填材及び軽量骨材の性質を表 2 に示す。

\section{表 2 充填材及び軽量骨材の性質}

\begin{tabular}{|c|c|c|c|c|c|c|}
\hline \multicolumn{3}{|c|}{$\begin{array}{c}\text { Type of Filler and } \\
\text { Aggregate }\end{array}$} & $\begin{array}{c}\text { Size } \\
(\mathrm{mm})\end{array}$ & $\begin{array}{c}\text { Specific } \\
\text { Gravity } \\
\left(20^{\circ} \mathrm{C}\right)\end{array}$ & $\begin{array}{c}\text { Water } \\
\text { Content } \\
(\%)\end{array}$ & $\begin{array}{l}\text { Organic } \\
\text { Impurities }\end{array}$ \\
\hline \multirow{3}{*}{ Filler } & \multicolumn{2}{|c|}{$\begin{array}{l}\text { Ground } \\
\text { Calcium } \\
\text { Carbonate } \\
\left(\mathrm{CaCO}_{3}\right)\end{array}$} & $<2.5 \times 10^{-3}$ & 2.70 & $<0.1$ & Nil \\
\hline & \multicolumn{2}{|c|}{$\begin{array}{c}\text { Hollow Glass } \\
\text { (HG) }\end{array}$} & $10-120 \times 10^{-3}$ & 0.45 & $<0.1$ & Nil \\
\hline & \multicolumn{2}{|c|}{$\begin{array}{c}\text { Hollow Fly Ash } \\
\text { (HF) }\end{array}$} & $10-350 \times 10^{-3}$ & 0.40 & $<0.1$ & Nil \\
\hline \multirow{7}{*}{$\begin{array}{c}\text { Fine } \\
\text { Aggregate }\end{array}$} & \multirow{2}{*}{$\begin{array}{c}\text { Expanded } \\
\text { Shale } \\
\text { (ES) }\end{array}$} & ES-1 & $2.5-5.0$ & 1.35 & $<0.1$ & Nil \\
\hline & & ES-2 & $<2.5$ & 1.62 & $<0.1$ & Nil \\
\hline & \multirow{3}{*}{$\begin{array}{c}\text { Foamed } \\
\text { Glass } \\
\text { (FG) }\end{array}$} & FG-1 & $2.5-5.0$ & 0.36 & $<0.1$ & $\mathrm{Nil}$ \\
\hline & & FG-2 & $1.2-2.5$ & 0.42 & $<0.1$ & Nil \\
\hline & & FG-3 & $0.3-1.2$ & 0.45 & $<0.1$ & Nil \\
\hline & \multicolumn{2}{|c|}{\begin{tabular}{|c|} 
Hollow Fused \\
Alumina (HFA)
\end{tabular}} & $0.1-5.0$ & 0.70 & $<0.1$ & Nil \\
\hline & \multicolumn{2}{|c|}{$\begin{array}{c}\text { Hollow Mullite } \\
\text { (HM) }\end{array}$} & $150-300 \times 10^{-3}$ & 0.40 & $<0.1$ & Nil \\
\hline
\end{tabular}

\section{3. 試験方法}

\section{1 供試モルタルの調製}

供試モルタルの謂合に先立って、充填材及び骨材の組 成を容積比によって、次のように定めた。

充填材組成 (1) $\mathrm{CaCO}_{3}: \mathrm{HG}=1: 2(\mathrm{HG})$

(2) $\mathrm{CaCO}_{3}: \mathrm{HF}=1: 2(\mathrm{HF})$

(3) $\mathrm{CaCO}_{3}$ (CC)

骨材組成

(1) $\mathrm{ES}-1: \mathrm{ES}-2=1: 2$ (ES)

(2) $\mathrm{FG}-1: \mathrm{FG}-2: \mathrm{FG}-3: \mathrm{HM}=2: 1: 1: 1$ (FG)

(3) $\mathrm{HFA}: \mathrm{HM}=4: 1 \quad(\mathrm{HFA})$

次に、各骨材組成当たり 3 種類の充填材組成を用いて、 骨材組成と充填材組成の組合せを 9 種類作り、各組合せ ごとに、JIS A 1181 (ポリェステルレジンコンクリート の強度試験用供試体の作り方)に準じて、結合材配合を $\mathrm{UP}: \mathrm{St}: \mathrm{CoO} \mathrm{c}: \mathrm{MEKPO}=100: 12: 0.5: 0.5$ (質量比) とし、表 3 に示す調合の供試モルタルを練混ぜた。
表 3 軽量ポリエステルモルタルの調合

\begin{tabular}{|c|c|c|c|}
\hline \multicolumn{3}{|c|}{ Mix Proportions by Volume } & \multirow{2}{*}{$\begin{array}{l}\text { Filler-Binder } \\
\text { Ratio, Vf/ } / \mathrm{b} \\
\text { (by Volume) }\end{array}$} \\
\hline $\begin{array}{c}\text { Binder } \\
(\mathrm{Vb})\end{array}$ & $\begin{array}{l}\text { Filler } \\
\text { (Vf) }\end{array}$ & Aggregate & \\
\hline \multirow{3}{*}{23.6} & 8.7 & 67.7 & 0.37 \\
\hline & 10.9 & 65.5 & 0.46 \\
\hline & 14.6 & 61.8 & 0.62 \\
\hline \multirow{3}{*}{24.4} & 9.0 & 66.6 & 0.37 \\
\hline & 11.2 & 64.4 & 0.46 \\
\hline & 15.1 & 60.5 & 0.62 \\
\hline \multirow{3}{*}{25.2} & 9.3 & 65.5 & 0.37 \\
\hline & 11.6 & 63.2 & 0.46 \\
\hline & 15.6 & 59.2 & 0.62 \\
\hline
\end{tabular}

\section{2 スランプ試験}

JIS A 1173 (ポリマーセメントモルタルのスランプ試 験方法)に準じて、供試モルタルのスランプ試験を行っ た。なお、スランプ試験に際して、スランプコーン引き 上げ60秒後のスランプを測定した。

\section{3 可使時間試験}

JIS A 1186 (ポリエステルレジンコンクリートの可使 時間測定方法）の触感法に淮じて、10、20及び $30^{\circ} \mathrm{C}$ の温 度条件下で調製した供試モルタル(充填材には を使用）の可使時間を測定した。なお、可使時間試験に 際しては、表 4 に示す結合材配合を用いた。

表 4 結合材の配合

\begin{tabular}{c|c|c|c}
\hline \multicolumn{3}{|c}{ Formulations by Mass } \\
\hline UP & St & CoOc & MEKPO \\
\hline \multirow{4}{*}{100} & & \multirow{3}{*}{0.25} & 0.25 \\
\cline { 3 - 4 } & \multirow{4}{*}{12} & & 0.5 \\
\cline { 3 - 4 } & & \multirow{3}{*}{0.5} & 0.75 \\
\cline { 3 - 4 } & & & 0.25 \\
\cline { 3 - 4 } & & \multirow{3}{*}{0.75} & 0.5 \\
\cline { 3 - 4 } & & & 0.75 \\
\cline { 3 - 4 } & & &
\end{tabular}

\section{4 供試体の作製}

供試モルタルを寸法 $40 \times 40 \times 160 \mathrm{~mm}$ に成形し、1日乾燥 $\left(20^{\circ} \mathrm{C} 、 50 \%\right.$ R. H. $)$ 養生後、15時間加熱 $\left(80^{\circ} \mathrm{C}\right)$ 養生を行い、 供試体を作製した。なお、加熱養生後の供試体の質量を その容積 (寸法 $40 \times 40 \times 160 \mathrm{~mm}$ として算出、 $256 \mathrm{~cm}^{3}$ ) で除 して、見挂け比重を求めた。

\section{5 曲げ及び圧維強さ試験}

JIS A 1184(ポリエステルレジンコンクリートの曲げ 
強度試験方法)及びJIS A 1183 (はりの折片によるポリエ ステルレジンコンクリートの圧縮強度試験方法)に準じ て、供試体の曲げ及び圧縮強さ試験を行った。なお、曲 げ及び圧縮強さを見掛け比重で除して、比強度を求めた。

3. 6 結合材と充填材から成るポリェステルペースト の圧縮強さ試験

JIS A 1181に準じて、3.1に示した組成を持つ充填材 と結合材のみを、充填材一結合材比が $0.37 、 0.46$ 及び 0.62 となるように練混ぜて、ポリエステルペーストを調 製した。ポリエステルペーストを寸法 $\phi 5 \times 10 \mathrm{~cm}$ に成形 L、1日乾燥 $\left(20^{\circ} \mathrm{C} 、 50 \%\right.$ R. H. $)$ 養生後、15時間加熱 $\left(80^{\circ} \mathrm{C}\right)$ 盖生を行い、供試体を作製した。その後、JIS A 1183に 準じて、供試体の圧縮強さ試験を行った。

\section{4. 試験結果}

図 1 には、軽量ポリエステルモルタルのスランプと結 合材量の関係を示す。結合材量の増加に伴って、軽量ポ リエステルモルタルのスランプは増大する傾向にある。

しかしながら、軽量骨材の種類によって、その傾向は大 きく異なり、ESを用いた軽量ポリエステルモルタルのス ランプは小さく、FG及びHFAを用いた軽量ポリェステル モルタルのスランプは大きい傾向にある。これらのこと から、軽量ポリエステルモルタルのスランプは、軽量骨 材の種類や結合材量に大きく影響されるものと推察され る。

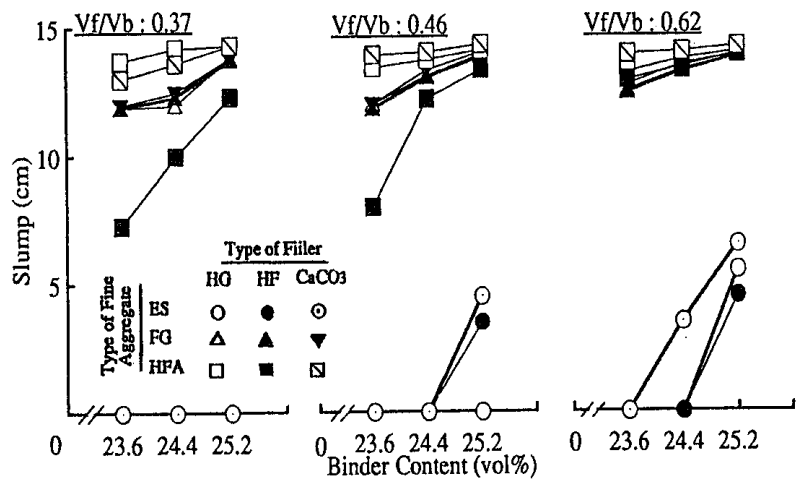

図1軽量ポリエステルモルタルのスランプと 結合材量の関係

図 2 から図 4 には、各試験温度下における各種軽量骨 材を用いた軽量ポリエステルモルタルの可使時閒と促進 剤及び触媒添加率の関係を示す。当然のことながら、温 度の上昇と促進剂及び触媒の添加率の増加に伴って、軽 量ポリエステルモルタルの可使時間は短くなる。又、触 媒添加率よりも、促進鼡添加率による可使時間の変化が 顕著であることから、触媒よりも促進剤の方が、軽量ポ リエステルモルタルの可使時間に及ぼす影響は大きい。

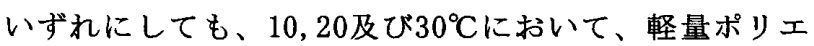
ステルモルタルの可使時間を、触媒と促進凧の添加率を
変化させて、十分に制御できることが分かる。

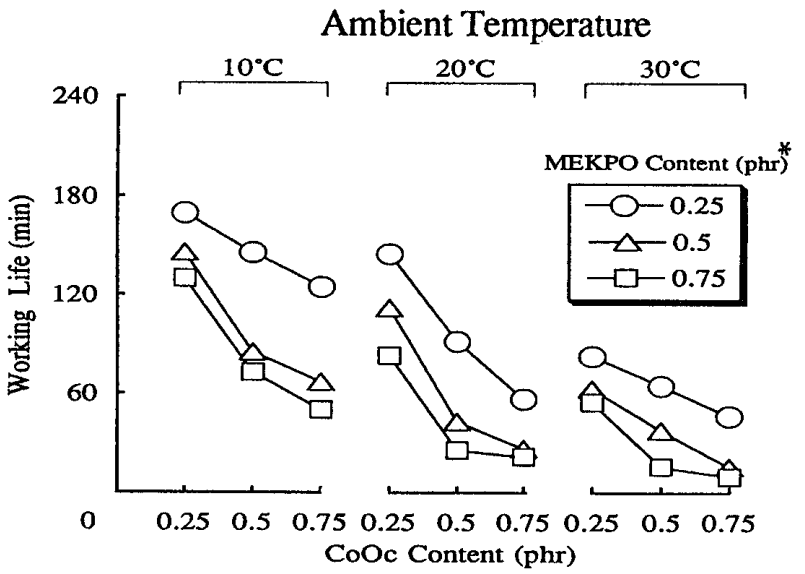

図2 ESを用いた軽量ポリェステルモルタルの 可使時間とCoOc及びMEKP0添加率の関係

* phr : Parts per hundred parts of resin

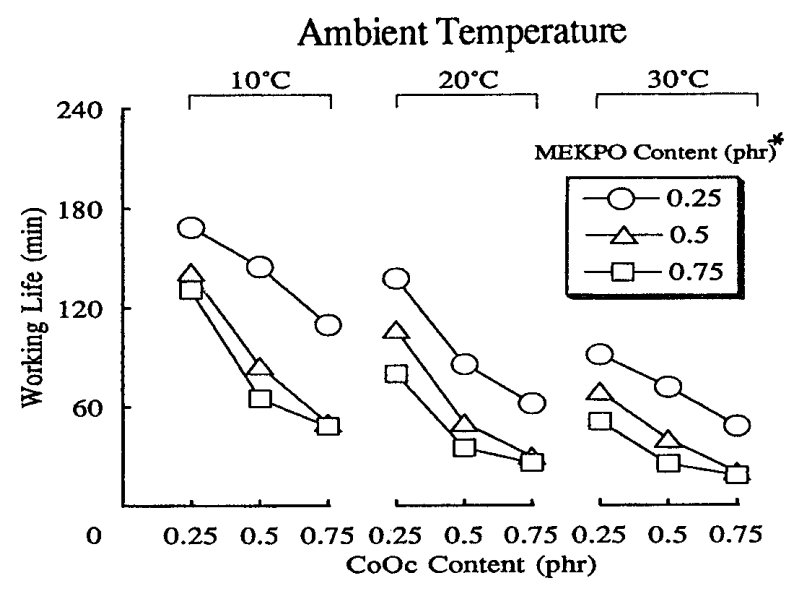

図3 FGを用いた軽量ポリエステルモルタルの 可使時間とCoOc及びMEKP0添加率の関係

* phr : Parts per hundred parts of resin

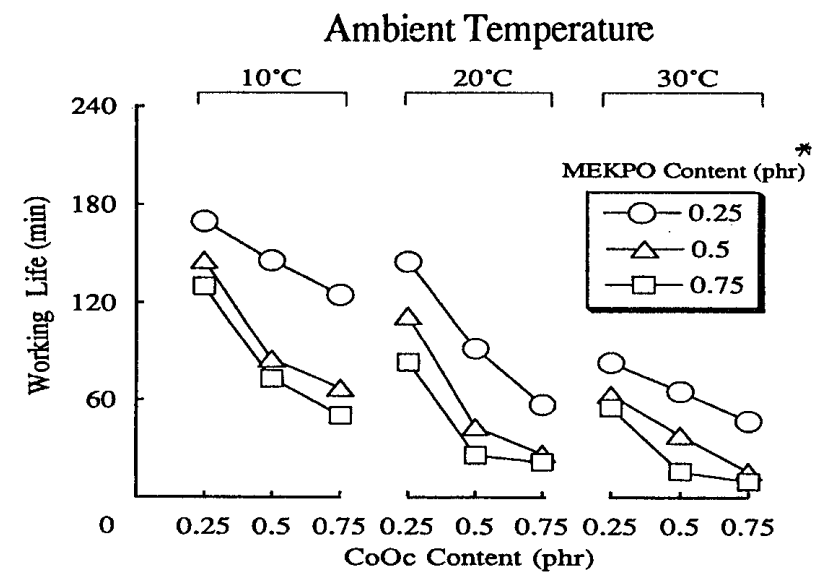

図 4 HFAを用いた軽量ポリェステルモルタルの 可使時間とCo0c及びMEKP0添加率の関係

* phr : Parts per hundred parts of resin 
図 5 から図 7 には、軽量ポリエステルモルタルの曲げ 強さと結合材量の関係を、図 8 から図 10 には、軽量ポ リエステルモルタルの圧縮強さと結合材量の関係を示す。 充填材及び軽量骨材の種類にかかわらず、軽量ポリエス テルモルタルの曲げ及び圧縮強さは、一部を除いて、結 合材量及び充填材一結合材比の增加に伴い增大する傾向 にある。これは、結合材量の増加に伴い、流動性が向

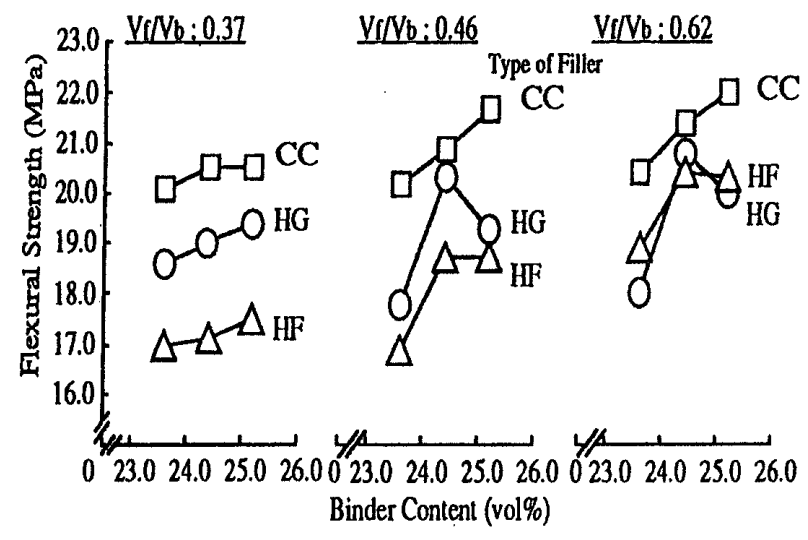

図5ＥSを用いた軽量ポリエステルモルタルの 曲け強さと結合材量の関係

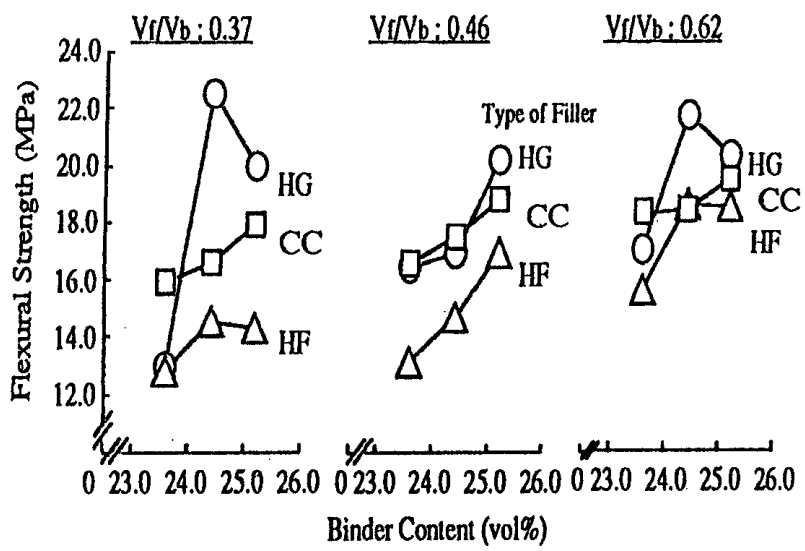

図7 HFAを用いた軽量ポリエステルモルタルの 曲け強さと結合材量の関係

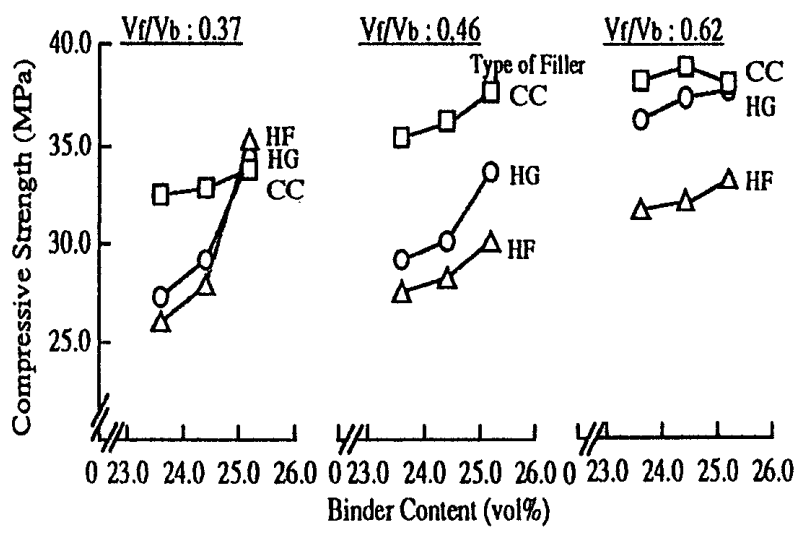

図9 FGを用いた軽量ポリエステルモルタルの 王縮強さと結合材量の関係
上し、より密実な組織が得られたこと、又、軽量骨材よ りも高い強さを持つ結合材の增加に起因するものと推察 される。軽量骨材の種類にかかわらず、軽量ポリエステ ルモルタルの曲げ及び圧縮強さは、充填材として $\mathrm{CaCO}_{3}$ を用いた時に最も高く、次いで、HG、HFの順となる。こ のことは、後述するポリェステルペーストの圧縮強さと 充填材の種類の関係に一致する。

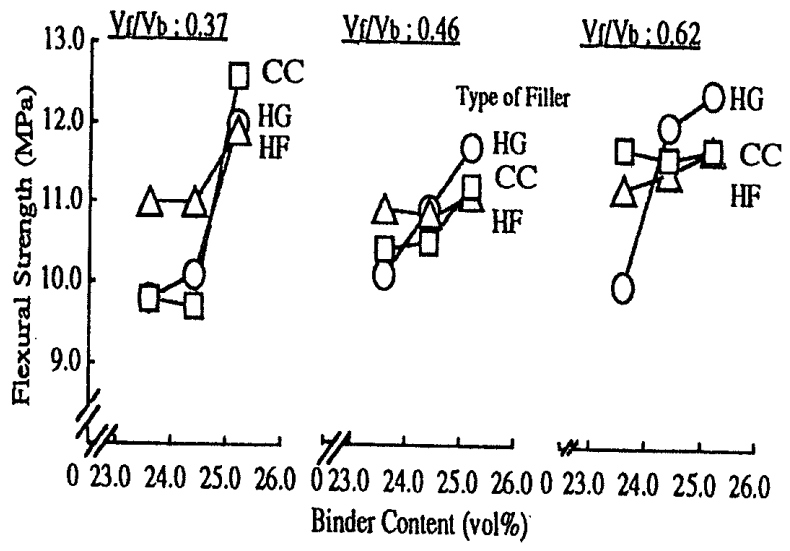

図6 FGを用いた軽量ポリエステルモルタルの 曲け強さと結合材量の関係

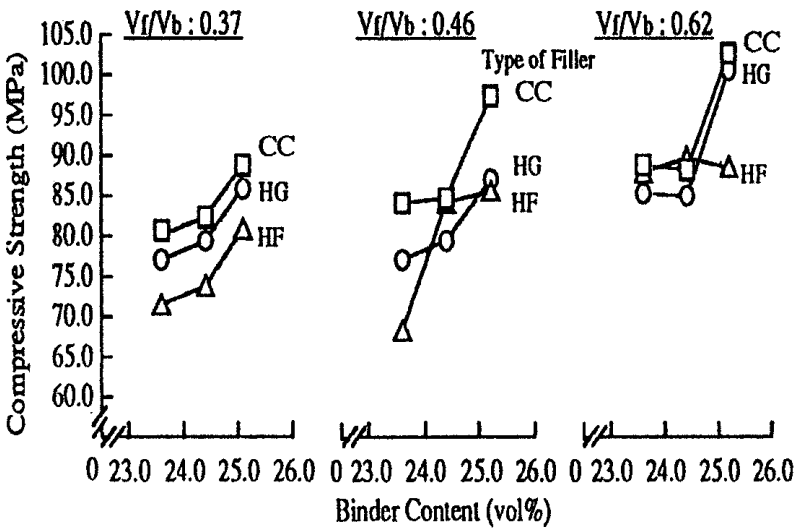

図8 ESを用いた軽量ポリエステルモルタルの 圧縮強さと結合材量の関係

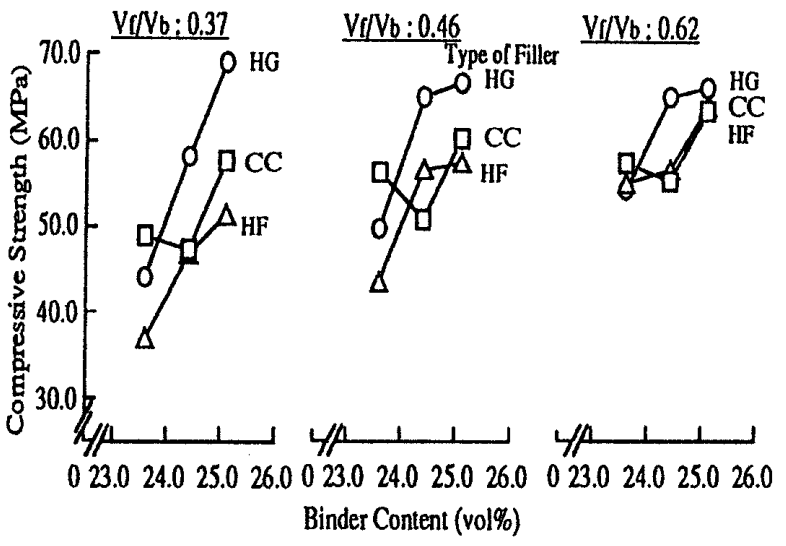

図10 HFAを用いた軽量ポリエステルモルタルの 王縮強さと結合材量の関係 
図 11 及び図 12 には、軽量ポリエステルモルタルの 曲げ及び圧縮強さと見掛け比重の関係を示す。軽量ポリ エステルモルタルは、見掛け比重が $0.86-1.73$ 範囲で、 9.7-22.0MPaの曲げ強さ(比強度：9.2-16.5MPa) 及び 23.0-100.8MPaの圧縮強さ(比強度：27.6-63.0MPa)を発 現する。一般に、軽量ポリエステルモルタルの強さは、 軽量骨材の種類に大きく影響される。軽量ポリエステル モルタルの曲げ及び圧縮強さは、一部を除けば、軽量骨 材として、ESを用いた時が最も高く、次いでHFA、FGの 順となる。本研究で用いた軽量骨材の比重は、ES $>H F A>$ FGの順に小さく、比重の小さいもの程、強さが低いと考 えられる。一般的に、軽量コンクリートの強度は、骨材 の強度に支配され、高強度を発現する軽量コンクリート を得るには、高強度の骨材を用いる必要があると考えら れているが、軽量ポリエステルモルタルにおいても同様 のことがいえる。

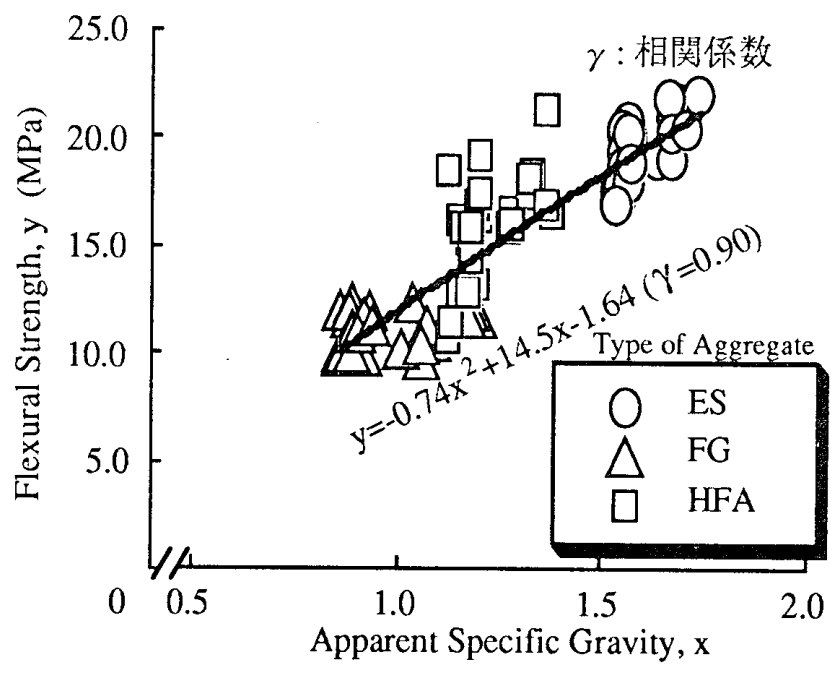

図 11 軽量ポリエステルモルタルの曲げ強さと 見掛け比重の関係

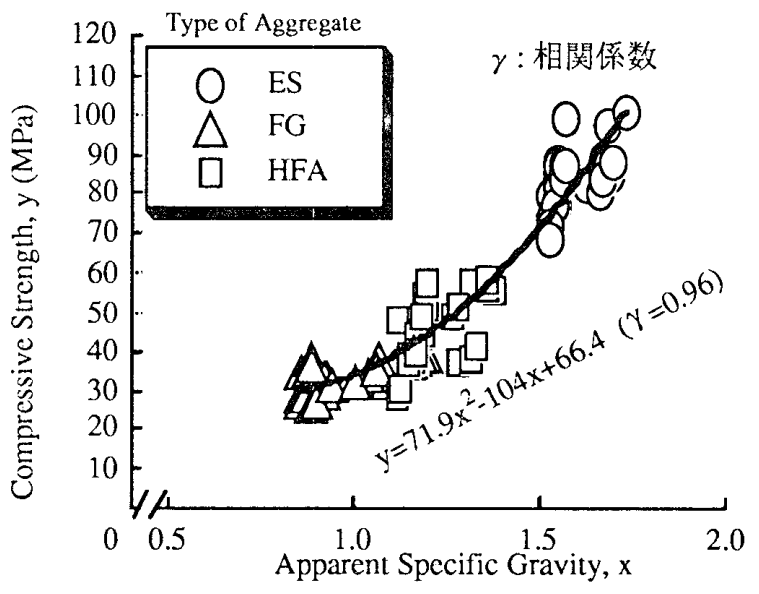

図 12 軽量ポリエステルモルタルの圧縮強さと 見掛け比重の関係
図 13 には、結合材と充填材からなるポリエステルペ 一ストの圧縮強さと充填材一結合材比の関係を示す。ポ リエステルペーストの圧縮強さは、充填材一結合材比り 增加に伴って若干增大寸る傾向にある。又、ポリエステ ルペーストの圧縮強さは充填材として $\mathrm{CaCO}_{3}$ を用いたも のが最も大きく、この圧縮強さに比べて、HG及びCBを用 いたポリエステルペーストの圧縮強さは相当に小さい。 これは、充填材の強さに起因するものと考える。

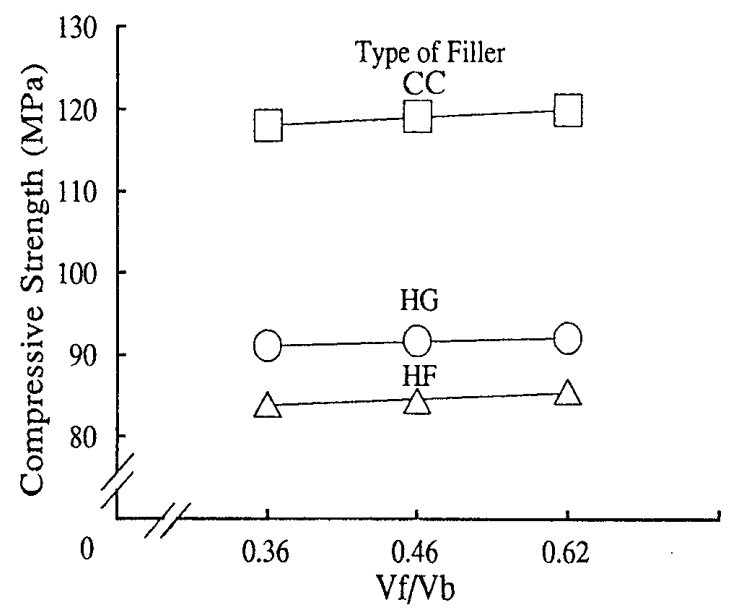

図 13 ポリエステルペーストの圧縮強さと 充填材一結合材比の関係

一般に、複合材料の性質を把握する場合、その性質を 構成成分それぞれの容積比で表す複合則の考え方が適用 できる ${ }^{21}$ 。ポリエステルコンクリートにおいても、使用 する骨材の圧縮強度と調合から、製造されるポリエステ ルコンクリートの圧縮強度を算定できるとされている ${ }^{3)} 。$ しかしながら、軽量ポリエステルモルタルにおいては、 使用する軽量骨材の強さの実測が困難である。そこで、 変数に軽量骨材の強さを含まず、充填材をマトリックス の成分と考え、ポリエステルペースト(結合材十充填材) の圧縮強さ及び容積分率を変数として、図 14 のように、 複合則に基づいて、軽量ポリエステルモルタルの圧縮強 さの算定を試みる。図中に示すように、軽量ポリエステ ルモルタルの圧縮強さは、軽量骨材別に次の実験式で表 される。

人工軽量骨材 : ES

$$
\sigma=1.01 \sigma_{\mathrm{p}} \mathrm{V}_{\mathrm{p}}+75.8\left(1-\mathrm{V}_{\mathrm{p}}\right)
$$

人工軽量骨材 : FG

$$
\sigma=0.563 \sigma_{\mathrm{p}} \mathrm{V}_{\mathrm{p}}+18.3\left(1-\mathrm{V}_{\mathrm{p}}\right)
$$

人工軽量骨材 : HFA

$$
\sigma=1.08 \sigma_{\mathrm{D}} \mathrm{V}_{\mathrm{D}}+22.8\left(1-\mathrm{V}_{\mathrm{D}}\right)
$$

ここに、。: 軽量ポリエステルモルタルの圧縮強さ $(\mathrm{MPa})$

$\sigma_{\mathrm{p}}:$ ポリエステルペースト（結合材十充填材） の圧縮強さ $(\mathrm{MPa})$

$V_{D}$ : ポリエステルペースト（結合材十充填材） の容積分率 


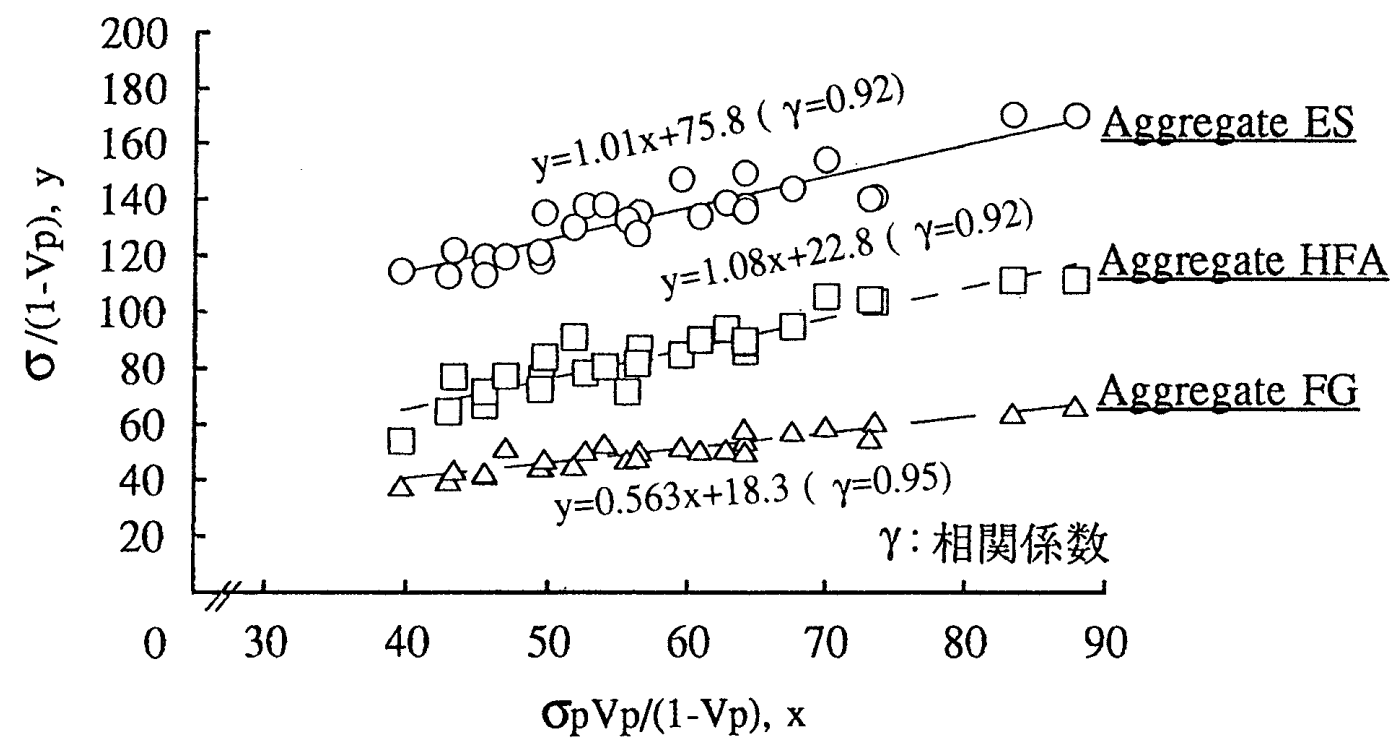

图14 軽量ポリエステルモルタルの圧縮強さの算定図

従って、ここで得られた圧縮強さ算定式を適用すると、 本研究で用いた調合の軽量ポリエステルモルタルの圧縮 強さを算定することができる。

\section{5. 結論}

以上の試験結果を結論づければ、次の通りである。

（1）結合材量の増加に伴って、軽量ポリェステルモル タルのスランプは増大する傾向にある。

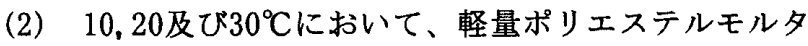
ルの可使時間は、触媒と促進剤の添加率を変化させ て制御できる。

（3）本研究で開発した軽量ポリエステルモルタルは、 見掛け比重が0.86-1.73の範囲で、9.7-22.0MPaの 曲げ強さ(比強度：9.2-16.5MPa) 及び23.0-100.8MPa の圧縮強さ(比強度：27.6-63.0MPa) 発現する。

（4）軽量ポリェステルモルタルの曲げ及び圧縮強さは、 結合材量並びに充填材一結合材比の増加に伴い增大 する傾向にある。

（5）本研究で用いた調合の軽量ポリエステルモルタル については、複合則を適用して提案した次の実用強 さ算定式を用いて、その圧縮強さを算定できる。

$$
\sigma=A \sigma, V_{p}+B\left(1-V_{p}\right)
$$

ここに、。：軽量ポリエステルモルタルの圧縮強さ (MPa)

$\sigma_{p}:$ ポリエステルペースト（結合材十充填材）

$V_{p}$ : ポリエステルペースト（結合材十充填材） の容積分率

A、B：軽量骨材の種類によって定まる実験定数 以上述べた軽量ポリエステルモルタルにおいて得られ た結論をもとに、軽量ポリエステルコンクリートの調合
要因を検討し、その調合設計法の確立を目指すことにす る。

本研究で開発した軽量ポリエステルモルタルは、それ 自体、鉄筋コンクリート構造物において、特に、天井や 壁など、施工時に補修材料が自重で落下する恐れのある 部位に有効に使えるものと考える。

一般に、ポリマーコンクリートは酎火性にそしいこと が一大欠点である。これの改善については、軽量ポリエ ステルコンクリートの開発が完了した時点で、その難然 化及び耐火被覆について検討する予定である。

\section{参考文献}

1) Kawakami, M., Tokuda, H. and Kagaya, M. : Some Physical Properties of Light Weight Polymer Concrete, Plastics in Material and Structural Engineering, ICP/RILEM/IBK Internationa1 Symposium, Part 1, Institute of Theoretical and Applied Mechanics, Czechoslovak Academy of Science, pp. 311-315, 1981.6

2) 藤井太一, 座古 勝: 複合材料の破壊と力学, 実教 出版, p. 13, 1992.4

3) Ohama, Y. and Demura, K. :Effect of Coarse Aggregate on Compressive Strength of Polyester Resin Concrete, The International Journal of Cement Composites, Vol. 1, No. 3, pp.111-115, 1979. 11 